\title{
11. Income-Contingent Student Loans for Thailand: Alternatives compared
}

\author{
Bruce Chapman and Kiatanantha Lounkaew \\ Crawford School of Economics and Government, \\ The Australian National University
}

\section{Summary}

In Thailand there is an ongoing debate concerning the most desirable form of higher education financing, with the critical concern being the form such a loan scheme should take. Conceptually, there are two generic possibilities: a mortgage-type loan, in which repayments are made on a consistent basis over a set period; and an income-contingent loan, in which the level and timing of repayments depend on a borrower's future income stream.

From 1996 to 2006, Thailand's preferred approach to higher education financing took the form of a mortgage-type loan known as the Student Loans Fund (SLF). The SLF involved targeted funds being allocated for both income support and tuition, with a time-limited repayment period of 17 years after graduation. Piruna et al. (2008) analysed the SLF with respect to two important dimensions: taxpayer-financed interest rate subsidies; and measures of so-called 'repayment hardships' - calculations of the proportion of borrowers' future incomes that would need to be allocated to SLF repayments.

Very similarly to the findings of Adrian Ziderman and others, Piruna et al. (2008) conclude that the SLF is associated with very substantial subsidies - perhaps of the order of 65 per cent. The source of the subsidy can be traced overwhelmingly to the interest rate regime. Consistent with these high subsidies, and in a unique contribution, they find also that the SLF has low rates of repayment hardship of about 4 per cent on average and only about 10 per cent for graduates whose future earnings are very low. In short, the SLF is a very generous scheme for students.

In this chapter, we seek to replicate some significant aspects of Piruna et al. (2008) with respect to various suggested forms of income-contingent loan schemes for Thailand. By definition, this type of loan has 'repayment hardship' set as a collection parameter-for example, in the Thai Income Contingent Allowance and Loan (TICAL) system explained below and in place in Thailand 
for 2007 only, the highest rate of repayment was set at 12 per cent of a borrower's income, and with the current Australian system the figure is 8 per cent. For these schemes, repayment hardships are not an issue.

There can be, however, considerable implicit interest rate subsidies with incomecontingent loan schemes. The major contribution of this chapter lies in the illustration of the extent of these subsidies for four different possible incomecontingent loan policies for Thailand. We show that the size of the subsidies is of the order of 25-40 per cent for a TICAL-type arrangement calculated for graduates with average earnings, and for this group these subsides can be almost eliminated with alternative loan schemes with a form of real rate of interest. But a more disaggregated, and preferred, approach to computing loan subsidies reveals that TICAL-type schemes have subsidies of 30-55 per cent, and even improved loan systems with respect to interest rate regimes have the potential to result in subsidies of 3-18 per cent, even for low levels of debt.

A major benefit of our approach is that we have used the same data, econometric techniques and present-value methods as employed by Piruna et al. (2008), providing a consistent basis from which to assess alternative loan schemes. We find that in design terms, and with respect to taxpayer subsidies, there seem to be viable possibilities for an income-contingent loan scheme for Thailand. But this conclusion is more credible for relatively low levels of debt than for the sizes of tuition fees that are more likely to be associated with higher-price private institutions. In this latter case, the subsidies of even well-designed schemes can be as high as 50 per cent. Whether or not Thai institutional and administrative arrangements are well suited to the collection of an income-contingent loan is a critical policy issue not addressed in what follows.

\section{Introduction}

In 2007, for one year only, Thailand introduced an income-contingent loan system for higher education, known as the Thai Income Contingent Allowance and Loan (TICAL) system. TICAL was based on Australia's Higher Education Contribution Scheme (HECS) - an income-contingent loan system in which tuition charges are collected through the income tax system depending on a student's future income. HECS was instituted in 1989, and similar student loan policies commenced throughout the 1990s and beyond in, among other countries, New Zealand, Chile, South Africa, Ethiopia, Hungary and the United Kingdom. Other countries - notably, Colombia and Israel-are involved currently in research-based debate on the usefulness of income-contingent loan approaches to higher education financing. 
This chapter examines the conceptual bases of alternative student loan systems, and it is argued that income-contingent approaches are generally seen as desirable arrangements compared with alternatives. Such an assessment is, however, associated with two extremely important qualifications: one is that the administrative institutions of a country are such as to allow efficacious collection of a former student's debt; and two, that an income-contingent scheme needs to be properly designed with respect to some key parameters.

We are unable to ascertain with complete certainty if potential Thai collection arrangements are such as to enable efficient and fair collection of an income-contingent loan, and we leave the answer to that critical question to administrative, tax and/or social security specialists. ${ }^{1}$ Our aim is instead to throw significant light on the second concern - the importance of design parameters with respect to the likely outcomes of such a system - with our focus on the critical issue of implicit taxpayer interest rate subsidies. Internationally, this is now perhaps the most important non-administrative design issue for an assessment of the efficacy of income-contingent loan schemes.

Interest rate subsidies, along with loan repayment hardships, have been explored by Piruna et al. (2008), who are concerned with analysis of the previous Thai student loan scheme, the Student Loans Fund (SLF). Piruna et al.'s (2008) and our analyses use exactly the same data set and empirical methods, so we can compare and contrast confidently the effects of disparate past and prospective Thai student loan arrangements.

While interest rate subsidies are a major aspect of our chapter, it is useful to make a comment on the other major component of Piruna et al.'s (2008) analysis: so-called repayment hardships associated with the SLF. The results of their research are summarised below, and it is important to recognise that one of the principal benefits of an income-contingent loan system is that, unless the loan is designed poorly, it is not possible to incur important repayment hardships, as measured by the proportion of a graduate's income that needs to be allocated to the repayment of a student loan. That is, because such a loan is repaid up to a maximum percentage of income, there will not be repayment hardships. In the Australian system, this maximum is 8 per cent, and for TICAL it is 12 per cent; for mortgage-type loans, these figures could be very different.

There are, however, important reasons to explore the findings of Piruna et al. (2008) with respect to implicit interest subsidies for the SLF, and, in this chapter, various forms of income-contingent loans for Thailand. As implied above, all the

1 The analysis below of requirements suggests the importance of being able to collect the debt on the basis of observed lifetime incomes, and this might imply for Thailand the use of the social security system instead of the income tax system. With the former, there are already income-contingent collections of funds for pensions. 
authors collaborated closely in the two exercises in order to be in a position to make similarly based assessments of the effects of the different schemes in terms of subsidies.

Piruna et al.'s (2008) results can be compared with our findings for two different interpretations of how TICAL might have worked in practice had it not been discontinued, as well as with an alternative proposed income-contingent loan scheme for Thailand. Two versions of the latter are explained and explored, with these variants having been motivated by our curiosity with respect to the possible role played by different forms of the requirement that former students cover, at least in part, the opportunity cost to the government of borrowing to finance the income-contingent loan. As with Piruna et al. (2008), we use not only average predicted lifetime graduate incomes for our empirical exercises, but also low, median and high estimates of incomes, and for both sexes.

Our estimates and calculations illustrate the empirical significance of different levels of income thresholds for repayment, and for disparate approaches to the imposition of real rates of interest for a wide spectrum of graduate incomes, and take into account the possible roles of graduate unemployment rates and potential loan losses associated with collection inefficiencies. The findings suggest that in design terms an income-contingent loan scheme is a viable option for Thailand, but this conclusion seems to be more credible for relatively low levels of debt than for the sizes of tuition fees that are more likely to be associated with higher-price private institutions.

\section{Traditional Student and Income-Contingent Loan Schemes: Conceptual issues}

\section{The Need for Government Intervention in Higher Education Financing}

A significant financing issue for higher education is that there is generally seen to be a case for both a contribution from students and a taxpayer subsidy (Barr 2001; Chapman 2006). An important question is: is there a role for government beyond the provision of the subsidy?

An understanding of the issue is facilitated through consideration of what would happen if there was no higher education financing assistance involving the public sector. That is, a government, convinced that there should be a subsidy, could simply provide the appropriate level of taxpayer support to 
higher education institutions, and then leave market mechanisms to take their course. Presumably, this would result in institutions charging students up-front on enrolment for the service.

There are, however, major problems with this arrangement, traceable in most instances to the potent presence of risk and uncertainty. This critical point was first raised by Friedman (1955). The argument can be best understood with reference to the nexus between labour markets and human-capital investments. The essential point is that educational investments are risky, with the main areas of uncertainty as follows. ${ }^{2}$

Enrolling students do not know fully their capacities for (and perhaps even true interest in) the higher education discipline of their choice. This means, in an extreme, they cannot be sure that they will graduate, with, in Australia, for example, about 25 per cent of students ending up without a qualification.

Even given that university completion is expected, students will not be aware of their likely relative success in the area of study. This will depend not just on their own abilities, but also on the skills of others competing for jobs in the area.

There is uncertainty concerning the future value of the investment. For example, the labour market - including the labour market for graduates in specific skill areas - is undergoing constant change. What looked like a good investment at the time it began might turn out to be a poor choice when the process is finished.

Many prospective students, particularly those from disadvantaged backgrounds, might not have much information concerning graduate incomes, due in part to a lack of contact with graduates.

These uncertainties are associated with important risks for both borrowers and lenders. The important point is that if the future incomes of students turn out to be lower than expected, the individual is unable to sell part of the investment to refinance a different educational path, for example. For a prospective lender-a bank - the risk is compounded by the reality that in the event of a student borrower defaulting on the loan obligation, there is no available collateral to be sold - a fact traceable in part to the illegality of slavery. And even if it was possible for a third party to own and sell human capital, its future value might turn out to be quite low, taking into account the above-noted uncertainties associated with higher education investments.

It follows that, left to itself-and even with subsidies from the government to cover the value of externalities - the market will not deliver propitious higher education outcomes. Prospective students judged to be relatively risky,

2 As discussed by Barr (2001), Chapman (2006) and Palacios (2004). 
and/or those without loan-repayment guarantors, will not be able to access the financial resources required for both the payment of tuition and to cover income support. There would be efficiency losses (talented but poor prospective students would be excluded) and distributional inequities (the non-attainment of equality of educational opportunity). Government intervention of some form is thus required.

The governments of most countries apparently understand the capital-market failure with respect to higher education financing, given that public-sector loan interventions are commonplace internationally. Until recently, government intervention often took the form of public-sector guarantees for commercial bank provision of education loans, but over the past decade or so this has increasingly involved income-contingent loans. While quite different in practice, both approaches are motivated in part by the recognition that, left alone, higher education markets will function poorly.

\section{The Costs and Benefits of Mortgage-Type Loans}

A possible solution to the capital-market problem described above used in many countries is the provision of student loans - either directly by the government or indirectly through guarantees of repayments to banks by the government in the event of default. Typically, and most simply, these loans involve fixed repayments, as, for example, with a house mortgage. While this seems to address the capital-market failure, it raises other problems.

Students face an important default issue. This is that some might be reluctant to borrow for fear of not being able to meet future repayment obligations. Not being able to meet repayment obligations has the potential to inflict significant damage to a person's credit reputation (and thus access to future borrowing for example, for the purchase of a house). These concerns imply that there will be less borrowing than there would be in the absence of this default concern.

A reluctance to borrow due to the uncertainty of repayment constitutes what might be labelled an ex ante default problem for prospective students. There is also an ex post problem, which is that a proportion of those students who took the credit risk of borrowing for a human-capital investment will end up not being able to repay because of low incomes. In these circumstances, default imposes a potentially large cost on those unlucky borrowers who do poorly in the labour market. Significantly, research suggests that members of the default group are predominantly those who ultimately experienced relatively high unemployment rates and relatively low earnings. ${ }^{3}$

3 Dynarski (1994) used the National Post-Secondary Student Aid Study and found strong evidence that experiencing low earnings after leaving formal education is a strong determinant of default. Importantly, 
The prospect and consequences of a student defaulting on a loan obligation are potentially critical issues for borrowing to finance human-capital investments, due to the uncertainties noted above. A consequence is that some eligible prospective students will not be prepared to take bank loans. This problem can be traced, in part, to the fact that bank-loan repayments are insensitive to the borrower's financial circumstances.

A final possible practical problem of government-guaranteed bank loans relates to the fact that in many countries loans of this type are not universally available, or available loan levels are limited. ${ }^{4}$ This is because loan provision and/or amounts available are usually means tested on the basis of family income. This raises the important issue explained by Carneiro and Heckman (2002) concerning the role of the sharing of financial resources within families. Some students will be unable to access necessary levels of borrowing and will face the same creditmarket failure as they would in the absence of a government guarantee of a bank loan. Making loans available on a means-tested basis (as is the case in the United States and Canada) suggests that some prospective students will have difficulties accessing the system.

The bottom line is that, even though government-assisted conventional loans are a common form internationally of public-sector involvement in higher education financing, such an approach has several apparently very significant weaknesses.

\section{The Costs and Benefits of Income-Contingent Loans}

A different approach to student financing involves income-contingent loans, such as Australia's HECS. The attraction of these schemes is that they can be designed to avoid many of the problems associated with alternative financing policies.

First, there is no concern with intra-family sharing so long as the scheme is universal. That is, no students would be denied access through the imposition of means-testing arrangements that could exclude some whose parents or partners are unwilling to help.

Second, given an efficient collection mechanism, there is no default issue as such for the government. That is, if the tax system works well and is used to collect the debt (at least for Australia, this is essential because the Australian Taxation Office is the only institution with reasonably good information on a former student's income), it is extremely difficult for the majority of graduates to avoid

borrowers from low-income households and minorities were more likely to default, as were those who did not complete their studies.

4 Eligibility for Canadian student loans is limited to less than half of all students (Finnie and Swartz 1996). 
repayment. There is a form of a default issue in that some students will not pay back in full, because income-contingent systems are designed to excuse some former students' payments because their lifetime incomes are too low. Harding (1995) calculates that the total repayments remaining uncollected because of the nature of HECS would be of the order of 20 per cent for the original scheme (when the repayment conditions were particularly generous for the student). Other reasons loans might not be repaid include death and emigration.

Third, because repayments depend on income, there should be no concerns by students with respect to incapacity to repay the debt, or hardships associated with repayments. That is, once an individual's income determines repayment, and so long as the repayment parameters are sufficiently generous, it is not possible to default for hardship because of a lack of capacity to pay. This is the critical practical advantage of income-contingent collection schemes: unlike any other form of assistance, there is insurance against default and repayment difficulties.

Income-contingent schemes have significant advantages over alternative financing arrangements, in that they can be designed to avoid the major problems of their alternatives. This does not make such approaches a panacea generally, however; for an income-contingent scheme to be made operational, it is essential that there is an efficient administrative collection mechanism.

The matter of collection is of great importance for the introduction of incomecontingent loans in countries without the necessary institutional apparatus. Chapman (2006) argues that the minimum conditions for a successful incomecontingent loan seem to be

1. accurate record keeping of the accruing liabilities of students

2. an effective collection mechanism with a sound and, if possible, computerised record-keeping system

3. an efficient way of determining with accuracy, over time, the actual incomes of former students.

While most Organisation for Economic Cooperation and Development (OECD) countries will have income tax or social security systems that enable efficient collection of income-contingent debts, it is very unlikely that developing countries have the capacity to meet requirement (3) above. This issue requires critical attention in the Thai policy context. 


\section{The Student Loans Fund, TICAL and the Need for Alternatives}

\section{The Recent History of Student Loans in Thailand}

A loan scheme for Thailand's higher education students, the SLF was introduced in 1996, and has been analysed extensively by Piruna et al. (2008) and Ziderman (2003). The main features of the loan scheme are documented in Piruna et al. (2008), with the most important design issues for our purposes being as follows.

The SLF is in essence a traditional student loan scheme, with a fixed repayment period of 15 years after a grace period of two years, but with the novel feature that the proportion of the total debt-repayment obligation increases with time, starting at 1.5 per cent in the first year and reaching 13 per cent of the total debt in the final year. This aspect of the SLF can be seen as a part-concession to the benefits of income-contingent loans, since the repayment obligations will be correlated with increases in average earnings with age, as is clear from the analysis presented in this chapter. What these arrangements mean for repayment hardship is summarised below.

An important feature of the SLF relates to the nature of the interest rate subsidies. As pointed out in Piruna et al. (2008) and Ziderman (2003), these arise principally from: the zero nominal interest rate in the period before repayment begins; and the fact that the nominal interest rate of 1 per cent per annum, when imposed, is significantly below the true cost of borrowing for the government of perhaps 2-3 per cent in real terms per annum. The importance of these arrangements in an understanding of the overall interest rate subsidies is summarised below.

In 2007, the SLF was suspended and was replaced with the (short-lived) TICAL. The main design features of TICAL, and its financial implications, are explained and examined in detail below. In 2008, TICAL was replaced with what is essentially a new form of the SLF, but with the same fixed repayment period of 17 years. This new scheme has not been analysed by Piruna et al. (2008) and it will not be explored here, but it is very likely that the new loan system's implications for both repayment hardship and interest rate subsidies are very similar to those of the SLF. 


\section{The Effects of the SLF in Summary: Repayment hardship and interest rate subsidies}

Piruna et al. (2008) analysed two critical aspects of the former Thai SLF: repayment hardships and interest rate subsidies. The former is defined as the proportion of a graduate's income that is used to repay the loan, and is calculated both for graduates earning average incomes in the periods of repayment and socalled 'unlucky graduates' who earn in the bottom 10 per cent of the graduate income distribution by age and sex.

For the same sample of graduates used in this chapter, and using the same methods to project graduate incomes by age and sex, Piruna et al. (2008) find that the measures of repayment hardship on average are about 4 and 3.5 per cent for females and males, respectively. For the 'unlucky graduates', the results are about 12.4 and 9.7 per cent for females and males, respectively. It is reasonable to describe these outcomes as fairly low-certainly compared with the situation in other countries with similarly motivated and designed student loan schemes. ${ }^{5}$

Related to the above finding is that the SLF delivers very considerable interest rate subsidies, of the order of 67 per cent overall-a finding very similar to that found also for the SLF by Ziderman (2003). These very high subsidies are explained by a combination of policy parameters, but by far the most important empirically can be traced to the fact that SLF debt is adjusted annually by a nominal rate of interest of only 1 per cent-implying a real rate of interest of about -3 per cent per annum. Interest rate subsidies are a very important aspect of the Thai student loan debate, and they are now considered further with respect to the design of alternative possible income-contingent loan schemes for the country.

\section{TICAL and an Alternative Form of an Income- Contingent Loan Described}

TICAL was motivated by the perceived benefits of income-contingent loans considered in section two, although it is reasonable to suggest that there are some controversial design aspects of the scheme. There are several important and arguably contentious design issues associated with the scheme that are addressed in our empirical exercises.

The first relates to the first income threshold of repayment, set at B192000 per annum, which seems to be very high given the age-earnings profiles of

5 Recent calculations by Bruce Chapman and Colombian education officials illustrate that for the ICETEX loan scheme in that country, the repayment hardship results for unlucky graduates are of the order of 35-45 per cent. 
graduates presented below. ${ }^{6}$ This matters particularly if the debt has no real rate of interest, since it is necessarily the case that the longer it takes to repay a government loan that does not have a real rate of interest, the greater is the size of the associated subsidy from taxpayers. A major goal in what follows is to illustrate the empirical significance of this feature of TICAL.

Because the first income threshold of repayment of TICAL seems to be very high, we suggest a different income-contingent loan model for Thailand for illustrative purposes, and we label this 'ILLUSTRATIVE'. It has two repayment features different to TICAL: 1) the first income threshold of repayment is very much lower, at B100 000 per annum; and 2) the rates of repayment we have chosen are much closer to those of HECS, meaning that they are considerably lower than is the case for TICAL, particularly at high levels of income. Table 11.1 presents the repayment thresholds and rates of income for the two broad schemes.

Table 11.1 Repayment thresholds and collection parameters (percentage of taxable income) $)^{7}$ of different income-contingent loan schemes for Thailand

\begin{tabular}{rrrr}
\hline TICAL & \multicolumn{2}{c}{ ILLUSTRATIVE } \\
\hline Annual income (baht) & $\begin{array}{c}\text { Collection } \\
\text { parameters }\end{array}$ & Annual income (baht) & $\begin{array}{c}\text { Collection } \\
\text { parameters }\end{array}$ \\
\hline Less than 192 000 & 0.00 & Less than 100 000 & 0.00 \\
\hline $192000-360000$ & 0.05 & $100000-110000$ & 0.03 \\
\hline $360001-840000$ & 0.08 & $110001-120000$ & 0.04 \\
\hline Higher than 840 000 & 0.12 & $120001-130000$ & 0.05 \\
\hline & & Higher than 130 000 & 0.06 \\
\hline
\end{tabular}

A second design issue concerns the indexation arrangements with respect to the income thresholds of repayments, and this is a critical point in trying to understand what the effects of TICAL might have been. The concern is that it is not clear if the income threshold for repayment of the loan was to be indexed, and to what, as is the case for all relevant parameters of Australia's HECS, for example. To address this, we raise two possibilities.

The first possibility is that the income thresholds are eventually indexed to average nominal wage increases, but we are unsure what this means in a Thai context in which regular indexing is typically not part of the economic policy

\footnotetext{
6 For example, from the data presented in this chapter, it would seem to take an average female graduate about 12 years before any TICAL repayments are made.

7 This form of collection is the same as that used in the Australian loan scheme, HECS, in which once a given threshold of income is reached, a given proportion of total income is owed. While this seems to imply an extremely high effective marginal tax rate at the first income threshold, work by Chapman and Leigh (2006) suggests this has only small behavioural effects.
} 
fabric. To illustrate the significance of this possibility, however, it is necessary that an indexation arrangement of some form is imposed and the one we have chosen is full (assumed to be 5 per cent per annum) wage indexation being imposed 10 years after the initiation of the policy, and continuing annually after that. This scenario of eventual indexation of the repayment thresholds is referred to as 'TICAL1'.

The second possibility is that the TICAL thresholds are not to be indexed, meaning that over time as nominal wages increase the threshold becomes effectively lower and graduates would increasingly be repaying their debts earlier; in the event of real interest rate subsidies, this would mean lower taxpayer subsidies over time. This unindexed scenario is referred to as 'TICAL2'.

A third, related and controversial aspect of TICAL is that there is no real rate of interest on the debt, with an adjustment being made annually to a student's or graduate's debt for changes in the consumer price index (CPI) only. This aspect of the scheme looks to be identical to Australia's HECS arrangement, but there is a critical difference. This is that for HECS there is a 20 per cent discount for an up-front payment of the tuition obligation, which in effect means that students choosing to take the debt are subject to a 25 per cent surcharge ${ }^{8}$ (meaning that effectively there is a blunt form of real interest rate for HECS). The motivation for analysing in depth the conceptual issues associated with interest rate regimes, and for providing an empirical approach to explore this further, is now considered.

\section{Understanding the Role of the Form of Real Interest Rates}

The issue of interest rate subsidies in student loan schemes is extremely important. Moreover, there are major differences between countries even with apparently similar approaches to income-contingent loan policies. As examples: given the write-off of the interest rate of loans in nominal terms in New Zealand, the effective interest rate for that country is negative in real terms; for both the United Kingdom and TICAL, the real rate of interest is zero; and for HECS, there is a surcharge on the debt once it is incurred, but the ongoing adjustment of the debt is equal only to the rate of price inflation.

There are important disagreements between researchers on the appropriate level and form of a rate of interest on the debt associated with income-contingent loans. Barr (2007) makes a compelling case that the Australian form, which uses a surcharge, introduces distortions in both efficiency and equity terms,

8 This can be explained as follows. If there is a charge of $\$ 1000$, a student may avoid the debt by paying $\$ 800$; this means that students paying later take on an additional 25 per cent - that is, $\$ 200 / 800$. 
although on average it still means that there is some attempt to require students to contribute to the government's opportunity costs of borrowing. Chapman (2006) argues that the issue is quite complex in the case of an income-contingent loan, since such schemes are designed to offer insurance against the costs of poor future outcomes; and, in the case of a former student experiencing low future incomes, they might find themselves in an ex post situation of accumulating high real debts due simply to unpredictable poor luck.

Three broad points can be highlighted.

1. There is a strong case for an income-contingent loan scheme to require borrowers to contribute to diminishing the costs of borrowing for the loan for the government (which must mean that the UK scheme and TICAL, and now the New Zealand system, have important design weaknesses).

2. In the circumstances in which loans are offered in part for income support (as they are in New Zealand, but not in Australia), the case for having an ongoing real rate of interest such as suggested by Barr is strong, since otherwise some borrowers will be able to use their loans to make profits in the commercial money market - at taxpayers' expense.

3. There might be a case for a surcharge instead of an ongoing real rate of interest for tuition charges if borrowers are averse to having rapidly increasing debts in times of ongoing low incomes - a possibility that seems to be recognised through most loan schemes having a so-called 'forgiveness' clause, after which all the outstanding loan is written off.

We are unable to determine with confidence what the correct form of a real rate of interest should be for income-contingent tuition charges in the Thai context, so in what follows we have designed two alternative forms of the suggested TICAL1 and TICAL2, and this is known as ILLUSTRATIVE. The first form is called 'ILLUSTRATIVEl', and this variant imposes the same rule as HECS by adding a surcharge of 25 per cent to the debt, after which the real rate of interest is zero (that is, with an ongoing CPI adjustment only).

The second is called 'ILLUSTRATIVE2', which has a conventional real rate of interest imposed on the debt of 3 per cent real per annum, with adjustments beginning immediately after the debt is incurred. ${ }^{9}$ It is a significant goal of our research to determine the extent to which these different approaches matter with respect to the extent of taxpayer subsidies, and whether the size of the debt matters to an assessment of the relative appeal of these different approaches. This last point might become very important if the income-contingent loan system is allowed to move to the private sector where tuition charges are much higher.

9 Very roughly, this is about the long-term government bond rate, at least for Australia. 


\section{The Data and Earnings Function Results}

\section{Motivation}

We are interested in estimating earnings functions in order to provide structure and understanding of the lifetime earnings streams of male and female graduates, on average. This will assist in an overall understanding of the Thai graduate labour market, allowing insight into increments to wages from additional education, and the internal rate of return to investing in a university education. In this sense, our single cross-section provides restricted but complementary information for the exercises reported in Lathapipat (2008).

More significantly, for the policy aspect of our exercise, the ordinary least squares (OLS) results will allow us to determine the extent of interest rate subsidies on average from our four different variants of income-contingent loans for Thailand. This is done by using predicted smoothed average earnings to ascertain the timing and structure of loan repayments under different debt obligation parameters.

It is also interesting and important for subsidy calculations to examine the extent to which interest rate subsidies vary between debtor groups with quite different ex post income levels. This is approached in a separate exercise explained and reported below by truncating the earnings data-our preferred method to the use of quantile regressions, for reasons to be explained. Our method reveals that the use of OLS to determine interest rate subsidies from different forms of income-contingent loans has the potential to overstate aggregate loan repayments and thus to understate loan subsidies. The differences are not trivial, and this matters for the policy debate.

\section{The Data}

We use cross-sectional individual survey data from the Labour Force Survey (LFS), collected in the third quarter of 2006. The LFS is administered by the National Statistical Office, and it contains information on individuals' characteristics such as age, marital status, household size, educational attainment, and geographical location, as well as job-related information such as employment status, occupation, earnings, and hours of work. The LFS covers every province in Thailand and has a total sample size of more than 200000 ; thus, it is the most comprehensive data set for the labour market available in Thailand to be used for analysing returns to education at the aggregate level. Summary statistics are presented in Table 11.2. 
Our analysis is restricted to individuals aged from fifteen to sixty. ${ }^{10}$ We have omitted: a very small number of individuals whose earnings are significantly different from the population at large; the self-employed; part-time workers, ${ }^{11}$ and those who work in the agricultural sector.

The major points are as follows. There are 19856 males and 17491 females in the sample. Earnings per hour are calculated as weekly earnings received from the main job divided by total hours worked in the main job per week, and gross hourly wages in 2006 for males and females are B52.47 and B54.68, respectively, and we have adjusted these to derive average annual earnings for men and women, of B106 769 and B108 385, respectively.

Binary variables $(0,1)$ are used to represent the highest educational qualification of each individual in the sample, and in the econometric work we use individuals who did not complete primary school as the reference point for comparisons. About 18 per cent and 13 per cent of males and females, respectively, have the highest qualification recorded as being primary-school level or lower, and about 32 per cent of males and 29 per cent of females have attained lower secondary or upper secondary education. The receipt of an undergraduate qualification differs markedly between males and females, with the proportions being 17 per cent for males and 33 per cent for females. ${ }^{12}$ Average hours of work a week are 45.7 for men and 44.9 for women.

One drawback of the LFS is that respondents are not asked how long an individual has been employed in paid work - an important variable in the estimation of the earnings functions. To deal with this issue, we have constructed the usual proxy, known as 'potential experience', which is the difference between age and the sum of total years of schooling and the minimum age required to begin school. Based on this calculation, average potential experience is 19.4 years for males and 17.3 years for females.

\footnotetext{
10 Sixty is the official retirement age in Thailand.

11 A part-time worker is defined as a person who works less than 20 hours a week.

12 These sex differences in university participation are commonly found in Thailand. It is an area of future research by one of the authors of this chapter.
} 
Table 11.2 Variable definitions and summary statistics

\begin{tabular}{|c|c|c|c|c|c|}
\hline \multirow[b]{2}{*}{ Variable } & \multirow[b]{2}{*}{ Definition } & \multicolumn{2}{|c|}{ Male } & \multicolumn{2}{|c|}{ Female } \\
\hline & & Mean & $\begin{array}{l}\text { Std } \\
\text { dev. }\end{array}$ & Mean & $\begin{array}{l}\text { Std } \\
\text { dev. }\end{array}$ \\
\hline \multicolumn{6}{|l|}{$\begin{array}{l}\text { Dependent } \\
\text { variables }\end{array}$} \\
\hline Earnings per hour & $\begin{array}{l}\text { Gross hourly wages from } \\
\text { main job in } 2006 \text { (baht) }\end{array}$ & 52.47 & 42.67 & 54.68 & 45.83 \\
\hline Annual earnings & $\begin{array}{l}\text { Gross annual earnings in } \\
2006 \text { (baht) }\end{array}$ & 106769 & 77680 & 108385 & 812491 \\
\hline \multicolumn{6}{|l|}{$\begin{array}{l}\text { Educational } \\
\text { variables }\end{array}$} \\
\hline $\begin{array}{l}\text { Incomplete } \\
\text { school }\end{array}$ & $\begin{array}{l}\text { Dummy }=1 \text { if did not } \\
\text { complete school }\end{array}$ & 0.178 & 0.383 & 0.154 & 0.361 \\
\hline Primary school & $\begin{array}{l}\text { Dummy }=1 \text { if highest } \\
\text { qualification is primary }\end{array}$ & 0.184 & 0.387 & 0.133 & 0.339 \\
\hline Lower secondary & $\begin{array}{l}\text { Dummy }=1 \text { if highest } \\
\text { qualification is lower } \\
\text { secondary }\end{array}$ & 0.178 & 0.383 & 0.123 & 0.329 \\
\hline Upper secondary & $\begin{array}{l}\text { Dummy }=1 \text { if highest } \\
\text { qualification is upper } \\
\text { secondary }\end{array}$ & 0.148 & 0.355 & 0.148 & 0.355 \\
\hline Diploma & $\begin{array}{l}\text { Dummy }=1 \text { if highest } \\
\text { qualification is diploma }\end{array}$ & 0.082 & 0.275 & 0.080 & 0.271 \\
\hline Undergraduate & $\begin{array}{l}\text { Dummy = } 1 \text { if } \\
\text { highest qualification is } \\
\text { undergraduate }\end{array}$ & 0.172 & 0.376 & 0.337 & 0.473 \\
\hline Postgraduate & $\begin{array}{l}\text { Dummy }=1 \text { if } \\
\text { highest qualification is } \\
\text { postgraduate }\end{array}$ & 0.020 & 0.140 & 0.025 & 0.025 \\
\hline \multicolumn{6}{|l|}{$\begin{array}{l}\text { Other } \\
\text { variables }\end{array}$} \\
\hline Hours per week & $\begin{array}{l}\text { Hours of work per week } \\
\text { in main job }\end{array}$ & 45.72 & 8.10 & 44.87 & 7.86 \\
\hline $\begin{array}{l}\text { Potential } \\
\text { experience }\end{array}$ & $\begin{array}{l}\text { (Maximum) time in paid } \\
\text { work in years }\end{array}$ & 19.38 & 10.89 & 17.32 & 10.14 \\
\hline $\begin{array}{l}\text { Number of } \\
\text { observations }\end{array}$ & & & 19856 & & 17491 \\
\hline
\end{tabular}




\section{OLS Earnings Functions}

The standard earnings equation is used in this study and is of the following form:

$\ln w_{i}=\mathbf{X}_{\mathbf{i}}^{\prime} \hat{\mathbf{a}}+\stackrel{\mathbf{a}}{\mathbf{i}}_{\mathbf{i}}$

in which $i=1,2,3, \ldots, n$ represent individuals, $w_{i}$ is the gross hourly earnings of individual $i$, and $\mathbf{X}_{\mathbf{i}}^{\prime}$ is a vector of characteristics that determine earnings.

We employ three variations of the model: the first uses years of schooling as a proxy for educational attainment; the second variant uses the education dummies described earlier; and the third extends the second model to include interaction terms between education dummies and potential experience. The last of these is essentially a relaxation of the restriction imposed in the second model, which constrains returns to experience to be identical between education levels. The estimations for these models are carried out separately for males and females.

Based on the years-of-schooling coefficient model, on average, the earnings increases for one additional year of education are about 11.2 per cent for males and 12.9 per cent for females. Our estimates are reasonably close to the results from previous studies. The results from this study and selected previous studies are now shown in Table 11.3 (see Appendix 11.1 for the regression result).

Table 11.3 Selected comparisons of returns-to-schooling estimates for Thailand

\begin{tabular}{|c|c|c|c|c|}
\hline Author & $\begin{array}{l}\text { Year of } \\
\text { data }\end{array}$ & Method & \multicolumn{2}{|c|}{$\begin{array}{c}\text { Return to one } \\
\text { additional year } \\
\text { of schooling }(\%)\end{array}$} \\
\hline $\begin{array}{l}\text { Psacharopoulos } \\
\text { (1994) }\end{array}$ & 1971 & $\begin{array}{l}\text { The coefficient on years of } \\
\text { schooling }\end{array}$ & & $\begin{array}{r}\text { Overall } \\
10.4\end{array}$ \\
\hline Patrinos (1995) & 1986 & $\begin{array}{l}\text { The coefficient on years of } \\
\text { schooling }\end{array}$ & & $\begin{array}{r}\text { Overall } \\
12.4\end{array}$ \\
\hline Patrinos (1995) & 1989 & $\begin{array}{l}\text { The coefficient on years of } \\
\text { schooling }\end{array}$ & & $\begin{array}{r}\text { Overall } \\
11.5\end{array}$ \\
\hline $\begin{array}{l}\text { Psacharopoulos } \\
\text { (1994) }\end{array}$ & 1972 & $\begin{array}{l}\text { Returns to education by level of } \\
\text { education and gender }\end{array}$ & $\begin{array}{r}\text { Male } \\
9.1\end{array}$ & $\begin{array}{r}\text { Female } \\
10.0\end{array}$ \\
\hline This study & 2006 & $\begin{array}{c}\text { The coefficient on years of } \\
\text { schooling }\end{array}$ & $\begin{array}{l}\text { Male } \\
11.2\end{array}$ & $\begin{array}{r}\text { Female } \\
12.9\end{array}$ \\
\hline
\end{tabular}

Source: Psacharopoulos and Patrinos (2002) and authors' (2008) estimate. 
Results from the dummies-and-interaction terms are reported in Appendix 11.1. The findings from this model are consistent with economic theory-that is, earnings increase with education and experience, with the rate of increase with experience falling over time. The earnings-experience slopes are relatively steep for graduates, although not by much; this is as expected-a prediction that follows from the general view that university graduates are more likely to be in higher-training jobs with concomitant steeper earnings-experience slopes.

The percentage differences in earnings associated with educational qualifications are shown in Table 11.4. The reference group is made up of individuals who did not complete school.

The data from Table 11.4 show that, on average, without any prior market experience, a male primary-school graduate earns 15 per cent higher than a male without any formal qualifications, and this commensurate figure for females is 14 per cent. A male and female with lower secondary education experience higher earnings by 25 per cent and 22 per cent, respectively. Upper secondary qualification increases earnings by 32 per cent for males and 35 per cent for females. Average male and female diploma-holders earn 58 per cent and 55 per cent, respectively, more than the 'incomplete school' individual, with the earnings advantage for university graduates 78 per cent for males and 86 per cent for females. These earnings advantages for postgraduate males and females are 102 per cent and 110 per cent, respectively.

Table 11.4 Percentage differences in earnings

\begin{tabular}{lrr}
\hline \multicolumn{1}{c}{ Educational attainment } & Male & Female \\
\hline Primary & 15 & 14 \\
Lower secondary & 25 & 22 \\
Upper secondary & 32 & 35 \\
Diploma & 58 & 55 \\
Undergraduate & 78 & 86 \\
Postgraduate & 102 & 110 \\
\hline
\end{tabular}

\section{Age-Earnings Profiles and Internal Rates of Return}

We use the estimation results in Appendix 11.1 to construct age-earnings profiles. ${ }^{13}$ These profiles are used to derive the earnings path for males and females with upper secondary qualifications and undergraduate qualifications. ${ }^{14}$

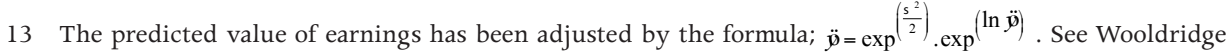
(2006) for details.

14 Observations with age greater than fifty-five years were dropped due the presence of several large outliers. 
The profiles for average males and females are shown in Figures 11.1 and 11.2, respectively. These profiles assume that the full working life of an average upper secondary high-school graduate is 42 years - from age eighteen to sixty. For those who decide to undertake undergraduate study for four years, the full working life is reduced to 38 years - from age twenty-two to sixty. As well, we adjusted the age-earnings profiles by 1.5 per cent to capture productivity growth, with the choice of this adjustment factor based on the average real wage growth in Thailand for 2003-06.

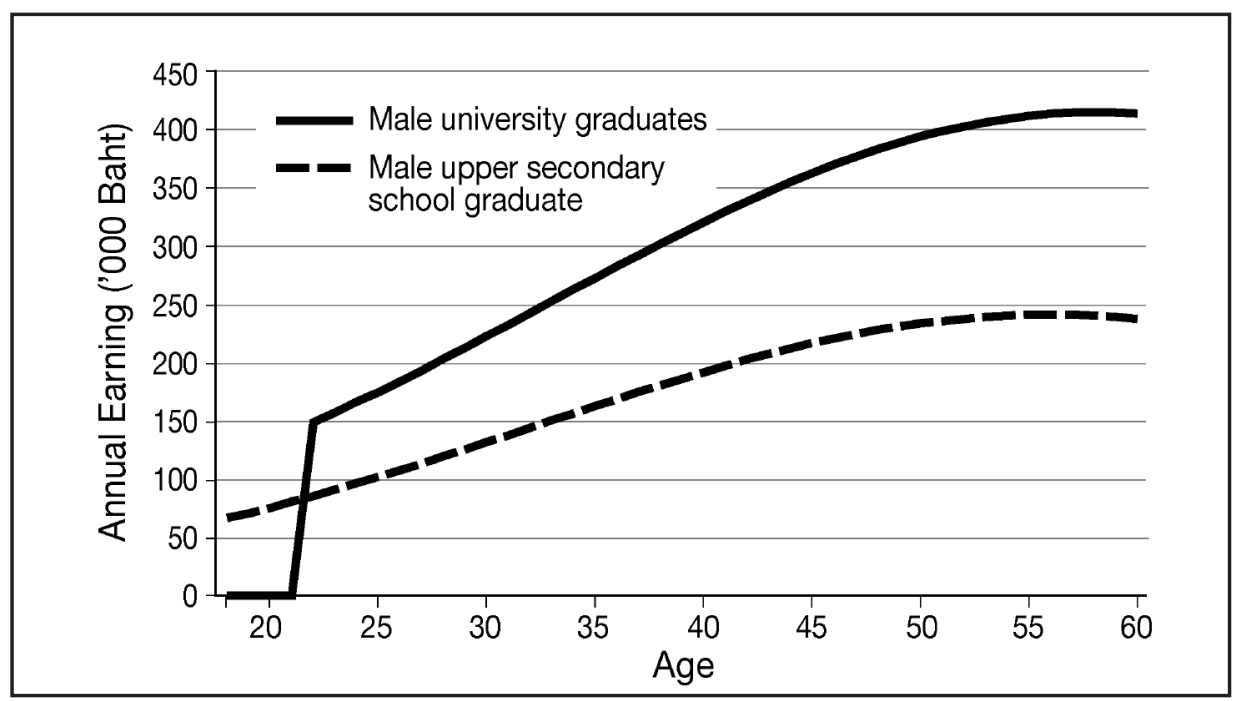

Figure 11.1 Average male age-earnings profiles: Thailand, 2006

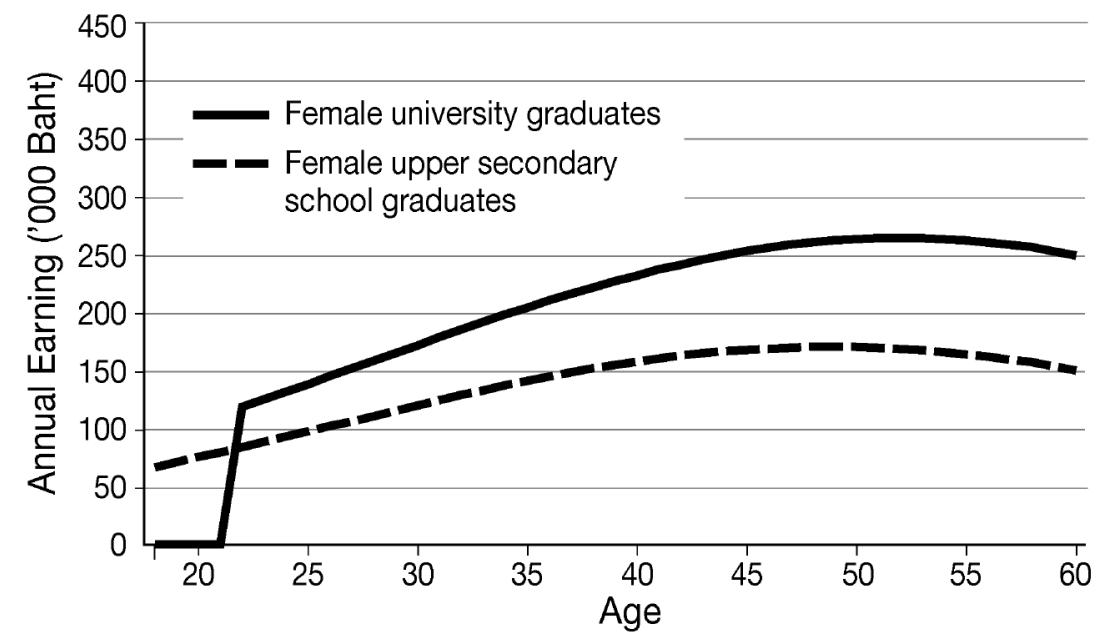

Figure 11.2 Average female age-earnings profiles: Thailand, 2006 
As can be seen from the figures, earnings increase at a decreasing rate with age (experience) for both upper secondary graduates and university graduates. The age-earning profiles for both male and female university graduates are (slightly) steeper than they are for secondary school graduates. It is of comfort to note that these relationships are familiar with respect to the findings for a large number of countries at different points of time.

We can use these results to calculate the so-called internal rate of return (IRR) to investment in university education - a measure of the value in earnings terms of process. Formally, the IRR is defined as the discount rate that equates the present value of additional benefits from the investment to the present value of the cost of obtaining the additional education. The benefits are additional earnings from higher education, and the costs are tuition fees plus the opportunity cost of not working in paid employment after the completion of upper secondary school. It should be noted that the result from the IRR estimate is contingent upon both the cost of investment and the earnings streams.

In our estimates, we assume that university graduates undertake study on a fulltime basis for four years and receive zero income at that time. The calculations have been carried out for a diversity of tuition fees-from B36 000 to B350 000 per program - which reflects very broadly the current range of Thai higher education annual tuition charges for different institutions. Table 11.5 shows the results with the IRR, and these range from 8 to 12.8 per cent per annum for males, and 4.5 to 7.9 per cent per annum for females - estimates that are roughly in line with international experience (see Psacharopoulos and Patrinos 2002). This familiarity should leave us with some confidence that the data and the methods employed are useful for describing the Thai graduate experience.

Table 11.5 IRR estimates (per cent per annum)

\begin{tabular}{ccrrr}
\hline \multicolumn{2}{c}{$\begin{array}{c}\text { Tuition prices by type of } \\
\text { institution * }\end{array}$} & $\begin{array}{c}\text { Total tuition fee } \\
\text { (baht) }\end{array}$ & Male & Female \\
\hline \multirow{2}{*}{ Public university } & Low price & 36000 & 12.79 & 7.93 \\
& High price & 144000 & 10.41 & 7.13 \\
\multirow{2}{*}{ Private university } & Low price & 192000 & 9.23 & 5.55 \\
& High price & 350000 & 8.04 & 4.48 \\
\hline
\end{tabular}

* average estimates from various universities

To this point the analysis has been based on average age-earnings profiles derived from OLS estimations. In order to better capture the heterogeneity of outcomes across different age-earnings groups, a truncated approach to estimation has been employed and this is now explained and the results are shown. A main reason that this more disaggregated approach is likely to be of considerable importance for the policy debate is that income-contingent loan 
schemes typically have a first income threshold of repayment; this can mean that a small proportion of the graduate population does not repay (even the nominal debt) in full and this could have marked effects on estimations of interest rate subsidies that will not show up with the use of OLS.

\section{Deriving Truncated Age-Earnings Profiles}

While it is of considerable interest to understand the earnings relationships at the mean of the data - which is what is happening with the use of OLS - a fuller understanding of the implications of different income-contingent loan schemes requires a more disaggregated method. We have approached this by doing the analysis separately for three parts of the lifetime graduate earnings distributions, and have thus divided the earnings data into three groups by year of age and sex: the bottom third, the middle, and the top third of earnings. ${ }^{15}$

There is an important reason for considering the earnings and loan experiences for different parts of the earnings distribution, which is that for TICAL1, TICAL2 and ILLUSTRATIVE1 (but not ILLUSTRATIVE2) ${ }^{16}$ there will be different subsidies depending on the lifetime earnings streams of hypothetical graduates; it is of interest to determine how big these are, and how much they differ between those earning low, medium and high lifetime incomes.

The truncation exercise provides an indication of the distributional effects of policy regimes and, related to this, the possible future contributions of taxpayers given marked movements in graduate income distributions. More significantly, and as noted above, when loan schemes have the potential to have less than full collection from some parts of the graduate earnings distribution, this needs to be explicitly modelled in order that we estimate implicit interest rate subsidies properly.

There is, however, a major limitation of this approach. It is the implicit assumption that graduates remain in the low, middle or top third of the earnings distribution throughout their lives, and this is clearly not going to be the case.

\footnotetext{
15 An alternative but similar way to have addressed this issue would be through the use of quantile regression techniques, which effectively divide the distributions into earnings categories. This approach, however, assigns weights to all the data points in the sample, with the weights being lower the further the data point is from the group under consideration. Because of this weighting procedure, we are unconvinced that such an approach usefully helps us understand the impact on subsidies of graduates in different thirds of the earnings distribution. Our approach using truncations implicitly assigns a weight in the regression of zero to all data points outside the group.

16 This is because ILLUSTRATIVE2 imposes the same real rate of interest on the borrowings as the real discount rate, and this must mean that there are no subsidies involved for any income groups, so long as all members of the group eventually pay off their debts in full.
} 
Even so, the approach employed allows us to determine upper boundaries of implicit interest rate subsidies (for the lowest third of earnings) and lower boundaries of implicit interest rate subsidies (for the highest third of earnings).

The estimated parameters from the truncated OLS estimations are shown in Appendix 11.1 and these have been used to construct age-earnings profiles for the three different graduate earnings groupings. ${ }^{17}$ These are shown for males and females in Figures 11.3 and 11.4, respectively.

The results illustrated in the figures show quite different earnings outcomes for graduates by age and sex. For both sexes, it is apparently the case that those in the highest third of the earnings distribution start out with earnings that are about 2.5 times higher than is the case for those in the bottom third of the distribution, and that this advantage increases considerably as age increases; at age fifty, for example, the earnings advantage of the top third compared with the bottom third has grown to about five times for females and to about 3.5 times for males. The size of these differences suggests strongly that estimated variations in implicit interest rate subsidies as a result of the parameters of the income-contingent loan schemes are likely to be very important.

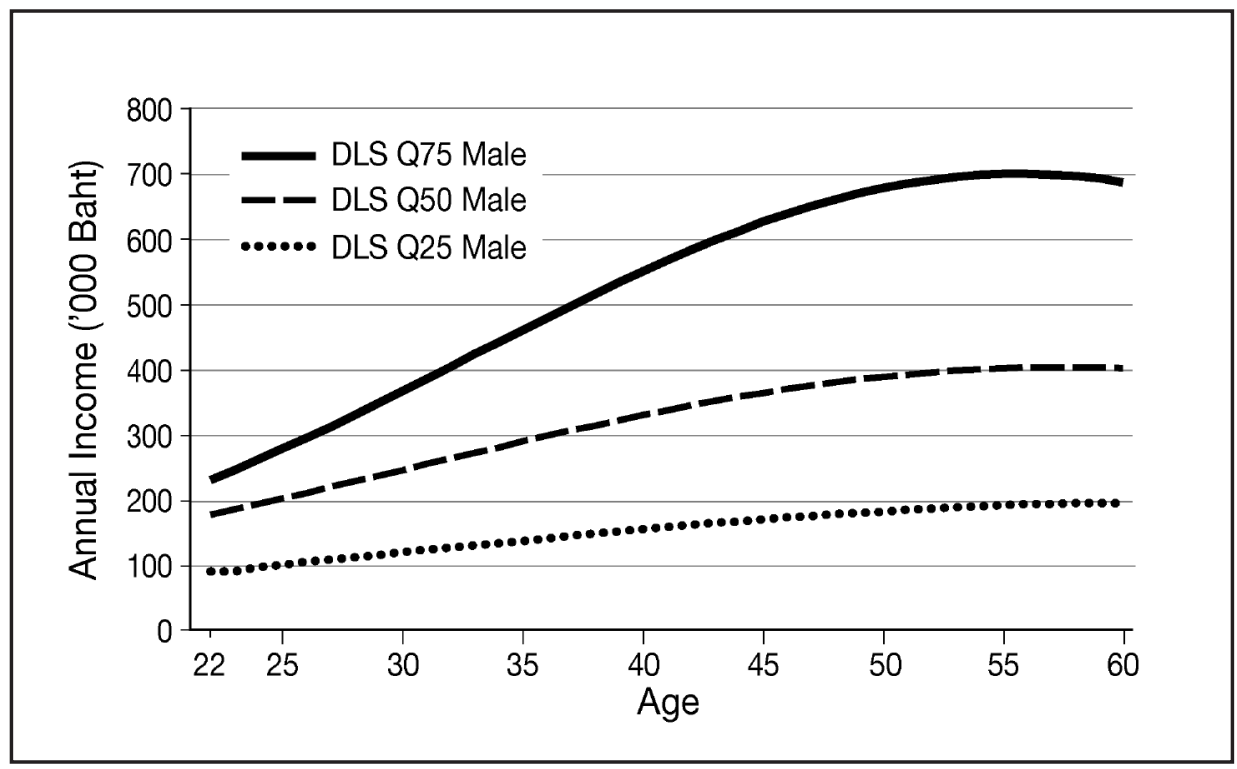

Figure 11.3 Male graduate age-earnings profiles for low, median and high earnings groups

17 The profiles are adjusted for productivity change by the same method used for adjusting the OLS predictions. 


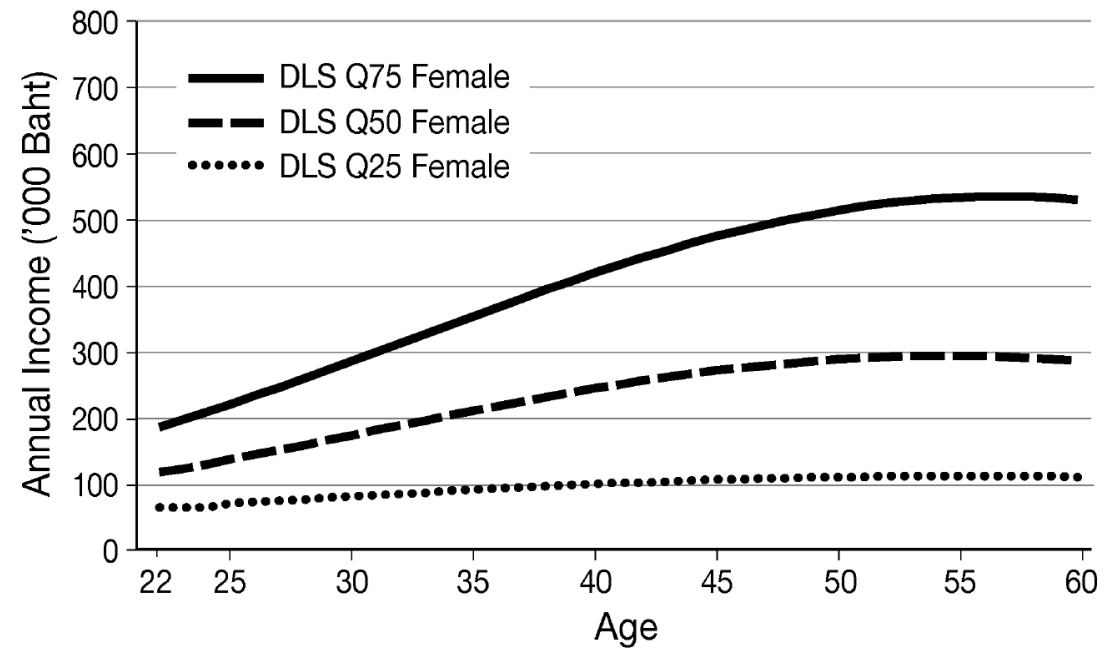

Figure 11.4 Female graduate age-earnings profiles for low, median and high earnings groups

\section{Loan Repayments and Interest Subsidies for Four Income-Contingent Loan Schemes}

\section{The Implicit Subsidy Calculation: Concepts and assumptions}

From a financial point of view, the efficiency and sustainability of loan programs depend significantly upon the level of loan recoverability. In turn, this is linked to the repayment conditions - the most important being: 1) the level and form of the real rate of interest on the debt; 2) the first income threshold of repayment; and 3) the rates of repayment as a proportion of income.

The difference between the present value of the sum of the repayment stream and the present value of the tuition fee paid through the loan scheme is called an 'implicit subsidy', and it is likely to be an unintended consequence as a result of the design of the financing scheme. The word 'implicit' is used to distinguish this form of subsidy from the intended tuition fee subsidy usually provided to public universities. 
For our exercises, and those reported in Piruna et al. (2008), we used the following formula for calculations of implicit subsidies. ${ }^{18}$

$\%$ of Implicit Subsidy $=\left[\frac{\sum_{\mathrm{t}}^{\mathrm{n}} \frac{\mathrm{T}_{\mathrm{t}}}{(1+\mathrm{r})^{t-1}-\sum^{N} \frac{\mathrm{P}_{1}}{(1+\mathrm{r})^{1+-1-1}}}}{\sum_{\mathrm{H}}^{\mathrm{n}} \frac{\mathrm{T}_{1}}{(1+\mathrm{r})^{t-1}}}\right] \times 100$

Where

$T_{1}=$ tuition fee paid in year $t$

$\mathrm{t}=$ year of tuition fee payment

$\mathrm{P}_{\mathrm{L}}=$ loan repayment in year $\mathrm{I}$

$I=$ length of time to repay the loan

$\mathrm{r}=$ discount rate

An implication of the above formula is that a loan package that takes longer to pay will result in a lower present value of repayment, and thus a higher subsidy, for all schemes except ILLUSTRATIVE2. ${ }^{19}$ This is an important issue for loan design and, as is shown below, it is a critical point with respect to whether or not it is possible to develop a workable income-contingent loan scheme for Thailand in circumstances in which debts are much higher than the low levels modelled here initially.

In what now follows, we present calculations of the implicit subsidy with respect to the collection of tuition fees for four possible income-contingent loan schemes for Thailand-described above and known as TICAL1, TICAL2, ILLUSTRATIVE1 and ILLUSTRATIVE2. The assumptions used in estimating the subsidies are as follows.

1. Real interest rates: zero for TICALl and TICAL2, as proposed for the original TICAL. A 25 per cent tuition surcharge with a zero real interest rate afterwards for ILLUSTRATIVE1, which is the same as is the case for HECS. A 3 per cent real rate of interest calculated from the beginning of the debt for ILLUSTRATIVE2, to represent a conventional method of covering the government's cost of borrowing.

2. Discount rate for the present value calculations: 3 per cent per annum in real terms. ${ }^{20}$

18 Subsequently and fortunately, we ascertained that it is the same formula derived by Adrian Ziderman (2003).

19 As long as the nominal debts are paid in full using a real rate of interest equal to the discount rate (both are set at 3 per cent per annum for ILLUSTRATIVE2), this must result in implicit interest rate subsidies of zero. 20 The choice of discount rate is somewhat subjective, but can be justified with reference to some data. For example, in Australia from December 2001 to 2004, accountants used a 5.6 per cent nominal discount rate, 
3. Full employment: the hypothetical graduates are assumed to be engaged in full-time year-round paid work.

4. Tuition fee (initially): the tuition fee is set at B100 000 for a four-year undergraduate degree. This is approximately equal to the weighted average tuition fee of public and private universities in Thailand, and is equivalent to the tuition fee imposed in Piruna et al.'s (2008) exercises. This assumption is relaxed later.

As noted above, we approach the interest rate subsidy calculations with both OLS and truncated estimations, beginning with the former.

\section{The Streams of Repayments and Interest Rate Subsidies: OLS}

Using these assumptions and average earnings profiles predicted from the OLS coefficients, we are able to construct repayment streams under all four schemes. The annual payments are shown in Figures 11.5 and 11.6.

A critical reason that the repayment streams differ is that the first income repayment threshold for the two versions of TICAL is almost twice as high as is the case for the two versions of ILLUSTRATIVE. The very high first threshold means that under TICALl an average male does not start to repay the debt until he is twenty-six years old, and the non-payment period of an average female is even longer, with repayment not beginning until she is thirty-two years old. It is also worth noting that the presumed indexation arrangement for the former TICAL is very important to the timing of repayment streams, with the nonindexed version resulting in repayments beginning three and six years earlier for males and females, respectively. A final obvious point is that the different forms of the real interest rate for ILLUSTRATIVE1 and ILLUSTRATIVE2 appear to deliver almost identical repayment streams.

All the above points are broadly true for both males and females, with the main differences in the results lying in the timing of repayments. Because they earn lower incomes, females start to repay later with TICAL1 and TICAL2, and repay for longer and at lower rates with ILLUSTRATIVE1 and ILLUSTRATIVE2.

Table 11.6 reports the implicit subsidies associated with these streams of repayment in combination with the interest rate parameters of each of the schemes.

and the average inflation rate was 2.3 per cent during that period, giving a real interest rate of 3.3 per cent per annum. Further, the real long-term bond rate is about the same as this. Piruna et al. (2008) also used a real rate of discount of 3 per cent. 
Financing Higher Education and Economic Development in East Asia

Table $\mathbf{1 1 . 6}$ Implicit interest rate subsidies for average graduates (per cent)

\begin{tabular}{lrrrr}
\hline & $\begin{array}{c}\text { TICAL1 } \\
\text { (indexed) }\end{array}$ & $\begin{array}{c}\text { TICAL2 } \\
\text { (not indexed) }\end{array}$ & $\begin{array}{r}\text { ILLUSTRATIVE1 } \\
\text { (25\% surcharge) }\end{array}$ & $\begin{array}{r}\text { ILLUSTRATIVE2 } \\
\text { (3\% real interest) }\end{array}$ \\
\hline Male & 31.54 & 26.20 & 2.03 & 0.01 \\
Female & 42.23 & 33.72 & 2.90 & 0.02 \\
\hline
\end{tabular}

The major points with respect to the implicit subsidies from the four incomecontingent loan policies are

1. having a zero real rate of interest, in combination with very high first income repayment thresholds, results in the high implicit interest rate subsides for both TICAL1 and TICAL2 - of about 30-40 per cent for the former, and 25-34 per cent for the latter

2. while the TICAL subsidies can be considered high and reflective of lessthan-perfect design, it is worth recording that these subsidies are much less than those reported in Piruna et al. (2008) for the SLF- of about 60 per cent

3. it is clear that having a form of real rates of interest for ILLUSTRATIVEl and ILLUSTRATIVE2 has a marked effect on calculations of subsidies compared with the two versions of TICAL

4. it is apparent that a 25 per cent surcharge with no further real interest rate adjustment (ILLUSTRATIVE1) delivers much the same implicit subsidies of about zero $^{21}$ as having an ongoing real rate of interest of 3 per cent per annum $^{22}$ (ILLUSTRATIVE2).

These findings are an important part of our contribution. The results from the use of basic econometric techniques promote for discussion the advantages of an income-contingent loan with a relatively low first income threshold of repayment, and with some form of a real rate of interest. The approach adopted thus far, however, reveals only subsidies for the schemes at the means of the data by age and sex, since our method uses OLS earnings function results. We now move to consider the subsidies associated with the schemes for quite different lifetime earnings distributions.

21 The slight difference between the subsidies found for ILLUSTRATIVE2 and zero is the result only of a rounding error.

22 This is very close to the results found for the HECS system for public-sector undergraduates (Chapman and Lounkaew 2008). 


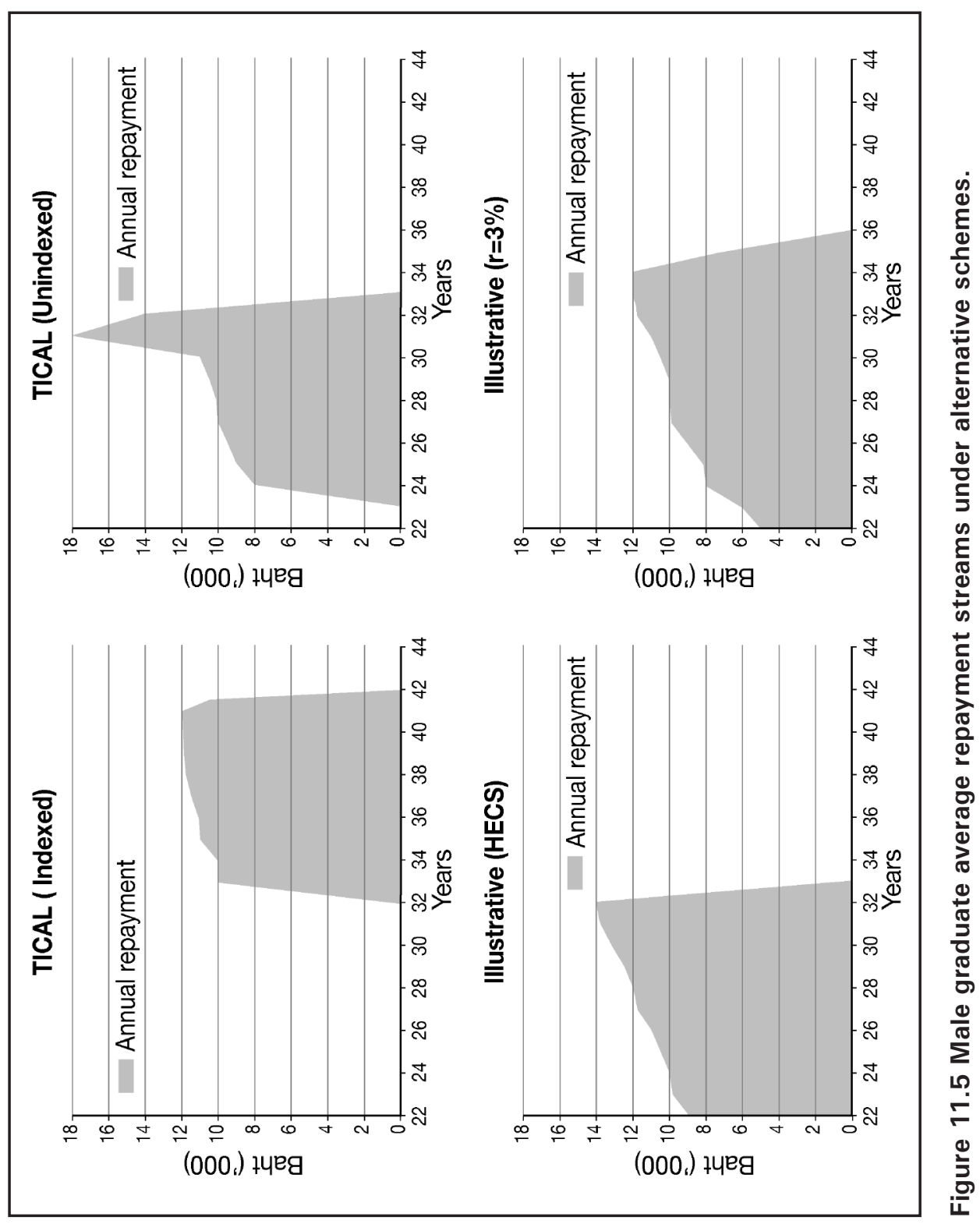




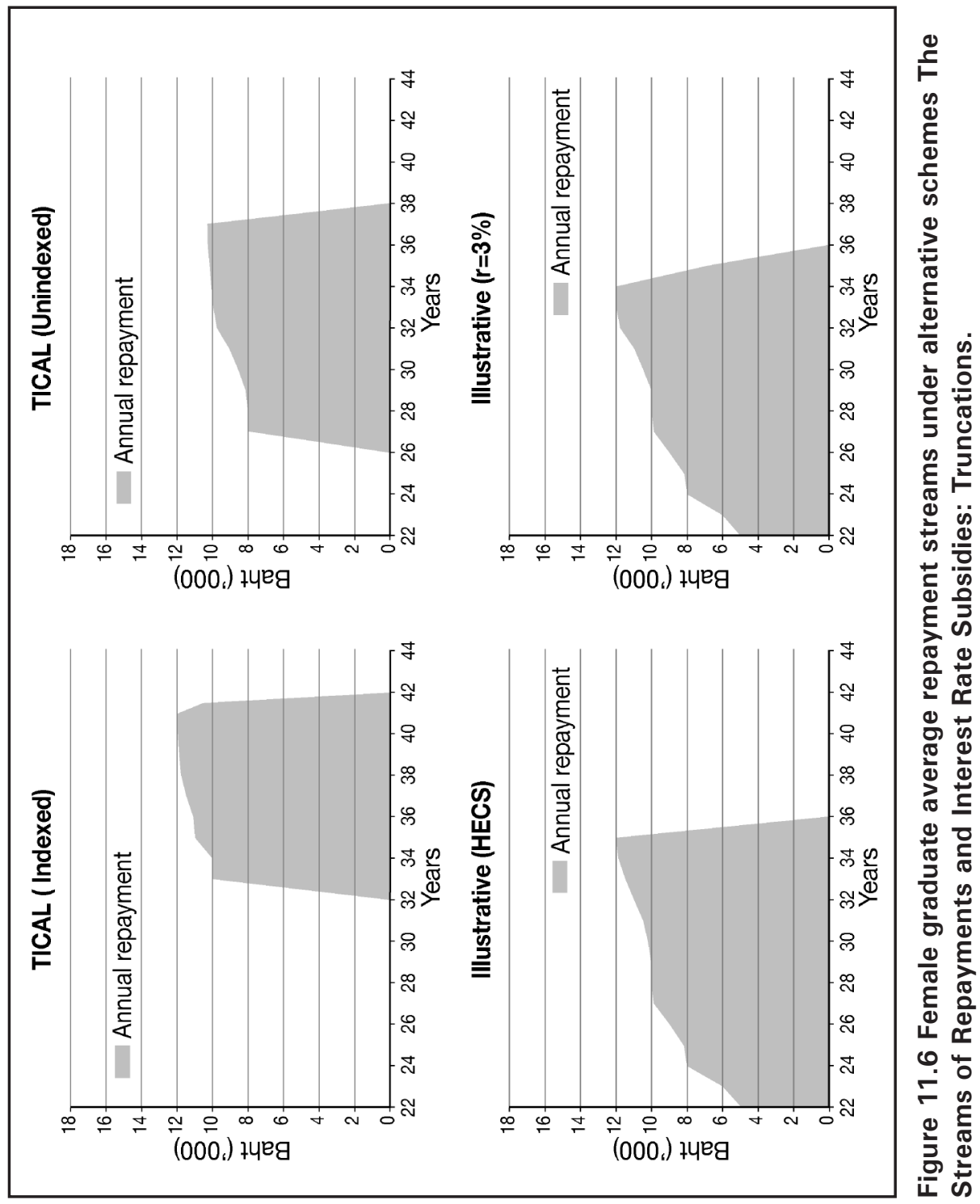


What now follows illustrates the streams of repayments and implicit subsidies of the three different lifetime earnings groups for both sexes illustrated in Figures 11.3 and 11.4: high earners (Q75), median earners (Q50), and low earners (Q25). ${ }^{23}$ Table 11.7 shows the implicit subsidies for males and females for each of the three lifetime earnings distributions for the four loan schemes.

Table 11.7 Implicit interest rate subsidies for low, median and high earnings groups (per cent)

\begin{tabular}{lrrrrr}
\hline Group & & $\begin{array}{l}\text { TICAL1 } \\
\text { (indexed) }\end{array}$ & $\begin{array}{l}\text { TICAL2 } \\
\text { (not indexed) }\end{array}$ & $\begin{array}{l}\text { ILLUSTRATIVE1 } \\
\text { (25\% surcharge) }\end{array}$ & $\begin{array}{l}\text { ILLUSTRATIVE2 } \\
\text { (3\% real interest) }\end{array}$ \\
\hline \multirow{2}{*}{ Male } & $\mathrm{Q} 25$ & 77.42 & 43.20 & 17.40 & 0.05 \\
\cline { 2 - 6 } & $\mathrm{Q} 50$ & 25.23 & 23.18 & -0.85 & 0.00 \\
\hline Q75 & 18.91 & 18.38 & -9.01 & 0.00 \\
\hline Female & Average & $\mathbf{4 0 . 5 2}$ & $\mathbf{2 8 . 2 5}$ & $\mathbf{2 . 5 1}$ & $\mathbf{0 . 0 1}$ \\
& $\mathrm{Q} 25$ & $100.00^{*}$ & $100.00^{*}$ & $58.90^{*}$ & $53.04^{*}$ \\
& $\mathrm{Q} 50$ & 42.71 & 33.42 & 1.42 & 0.02 \\
& $\mathrm{Q} 75$ & 20.62 & 20.62 & -6.92 & 0.00 \\
\hline & Average & $\mathbf{5 4 . 4 4}$ & $\mathbf{5 1 . 3 5}$ & $\mathbf{1 7 . 8 0}$ & $\mathbf{1 7 . 6 9}$ \\
\hline
\end{tabular}

An important aspect of the data from Table 11.7 needs to be explained, and this relates to the measure of the so-called 'average'. The calculation is the average of the three cohort-specific implicit taxpayer-subsidy calculations and can be interpreted with the use of the following example with respect to the findings for males under the TICALl scheme.

The results suggest that if there are 100 men taking TICAL1 loans, about 33 of them will earn in the bottom third of graduate earnings for the period in which the loan is collected, and for this group the estimated subsidy is about 77 per cent; an important part of this subsidy can be attributed to the fact that when the retirement age is reached, the loan is not paid off in full (in nominal terms). There will also be 33 men in the top third of graduate earnings in the period in which the loan is collected and for this group the estimated subsidy is about 19 per cent. Combined with the subsidy of about 25 per cent for the middle third of the male graduate earnings distribution, we can then calculate the (weighted) average for males as a whole under TICAL1. In this case, the answer is about 40 per cent $([77+25+19] / 3)$.

The strength of this calculation compared with the use of earnings data at the mean only is that it broadly takes into account the importance of subsidy differences across the earnings distribution. This must matter because incomecontingent loans require no repayments from debtors at the time that they experience low earnings, meaning that there are important asymmetries with 
respect to collection above and below the first (and later) income threshold at which repayments exist. Our method is necessarily more accurate than the estimates using OLS only.

The major points with respect to the implicit subsidies from the four incomecontingent loan policies taking into account the earnings distributions are

1. in all cases - except for males in ILLUSTRATIVE1 and ILLUSTRATIVE2estimates of implicit interest rate subsidies are higher than is the case for the calculations done at the mean only

2. with TICAL1, the subsidies are now calculated to be about 40-55 per cent for males and females, which is not very different to the estimates from Piruna et al. (2008) for the SLF, of about 65 per cent

3. with TICAL2, the subsidy for males remains relatively low-about 28 per cent-but increases to more than 50 per cent for females

4. with both ILLUSTRATIVE schemes, the subsidies remain about zero for males - an interesting component of this result being that for males in the top third of the earnings distribution under ILLUSTRATIVE1, there is a negative subsidy of 9 per cent; this is because the 25 per cent surcharge on the debt represents an effective real rate of interest in excess of 3 per cent per annum

5. with both ILLUSTRATIVE schemes, the average subsidy for females increases to about 18 per cent, and this is due almost entirely to the fact that the subsidies for females in the bottom third of the earnings distribution are very large (59 and 53 per cent for ILLUSTRATIVE1 and ILLUSTRATIVE2, respectively). This important finding can be traced to the fact that a large proportion of women experiencing low earnings have unpaid debt at the end of their working lives and thus the end of their debt repayments - of about 45 per cent.

The final point above is critical to our understanding of the potential for having an efficacious income-contingent loan scheme for Thailand. It means that, with reasonable repayment parameters and a real rate of interest, there remain important subsidies associated with income-contingent loan schemes for some groups. This is because the lifetime earnings of some graduates are not sufficient to repay the debt in full, and this is traceable to the fact that Thailand's per capita real incomes are relatively low when considered in an international context. This is unlike the situation in many countries with income-contingent loans such as Australia, New Zealand and the United Kingdom.

The results of Table 11.7 imply that schemes with design arrangements similar to TICAL are associated with very considerable subsidies and their level might be such as to suggest that alternative income-contingent loan policies are more 
appropriate. While the subsidies for schemes with forms of a real rate of interest and a much lower first income threshold of repayment are not insignificant, for the policy debate, it could be concluded that arrangements of this kind are acceptable with respect to taxpayer contributions.

It needs to be recognised, however, that our subsidy calculations have been undertaken for a total tuition debt of $\mathrm{B} 100000$, and it will certainly be the case that with higher charges - and thus higher debt - these subsidies will increase. This issue matters with respect to the coverage of an income-contingent loan for Thailand because outside the public sector, university tuition charges are generally and significantly higher.

\section{Interest Rate Subsidies for Higher Debts}

The exercises reported above involve estimations of implicit subsidies from income-contingent loans of various forms for a total tuition charge of B100 000 . While it can be argued that this is appropriate and typical for public-sector universities in Thailand, the story is different in the case of the private sector, where charges are much higher than this.

Our best estimate of a typical tuition charge for the private sector is a total of about B350 000. ${ }^{24}$ Assuming an income-contingent loan facility is offered by the government to cover this charge, we are able to estimate the implicit subsidies associated with the four schemes. The calculations are presented in Table 11.8.

The main points from Table 11.8 are

1. with a much higher charge of $\mathrm{B} 350$ 000, the implicit subsidies are higher for all four schemes, although the increases for TICAL1 and TICAL2 - to between 44 and 63 per cent - are not as high as the increases for ILLUSTRATIVE1 and ILLUSTRATIVE2; this is due to the fact that both TICAL arrangements involve quite high collection rates (of up to 12 per cent of income) at higher levels of earnings

2. with the higher charge, there is now very little difference between the subsidies associated with TICAL1 and TICAL2 and those found for the SLF and reported in Piruna et al. (2008)

3. having a surcharge of 25 per cent on the loan and no real rate of interest after the debt is incurred (ILLUSTRATIVEl) is associated with quite high subsidies - of about 38 for males and 51 per cent for females

24 This is about the same as tuition fees for the undergraduate business program at Assumption University. 
4. even with an income-contingent loan with an ongoing real rate of interest of 3 per cent per annum (ILLUSTRATIVE2), high charges are associated with important levels of subsidies - of about 17 per cent for males and 34 per cent for females.

Table 11.8 Implicit interest rate subsidies for low, median and high earnings groups with high debts (per cent)

\begin{tabular}{rrrrrr}
\hline \multirow{2}{*}{ Group } & & $\begin{array}{c}\text { TICAL1 } \\
\text { (indexed) }\end{array}$ & $\begin{array}{c}\text { TICAL2 } \\
\text { (not indexed) }\end{array}$ & $\begin{array}{r}\text { ILLUSTRATIVE1 } \\
\text { (25\% surcharge) }\end{array}$ & $\begin{array}{r}\text { ILLUSTRATIVE2 } \\
\text { (3\% real interest) }\end{array}$ \\
\hline \multirow{2}{*}{ Male } & 025 & $93.55^{*}$ & $66.38^{*}$ & 49.29 & $50.41^{*}$ \\
\cline { 2 - 6 } & 050 & 40.55 & 35.72 & 35.18 & 0.00 \\
\hline \multirow{2}{*}{ Female } & Q75 & 30.30 & 28.47 & 30.04 & 0.00 \\
& Q25 & $100.00^{*}$ & $100.00^{*}$ & $84.33^{*}$ & $86.58^{*}$ \\
& Q50 & 54.28 & 45.15 & 38.08 & $16.07^{*}$ \\
& Q75 & 36.10 & 30.62 & 31.42 & 0.00 \\
\hline & Average & $\mathbf{6 3 . 4 6}$ & $\mathbf{5 8 . 5 9}$ & $\mathbf{5 1 . 2 8}$ & $\mathbf{3 4 . 2 3}$ \\
\hline
\end{tabular}

These findings are very important for Thailand's higher education financing debate, since they imply that widespread reform of student loans, including their provision for relatively high-cost courses, is likely to involve sizeable taxpayer subsidies. We have not determined the possible overall costs for the government of broadly based coverage, and these might not be such as to undermine the basis for a universal income-contingent loan facility since we note that private universities apparently enrol about 15 per cent of all undergraduates (National Statistical Office 2006b).

On the other hand, the income-contingent loan schemes under consideration for our exercises have involved debts for tuition only. Since additional loans for income support would also seem to be a propitious aspect of higher education financing reform, the level of debts modelled, of B350 000, could well be required for the public sector as well.

\section{Conclusion}

There is an ongoing and very important debate in Thailand concerning higher education financing policy. For the 10 years prior to 2007, a traditional mortgagetype loan - known as the Student Loans Fund (SLF) - was in operation, and, after this was suspended, a system very similar to the SLF was reintroduced in 2007. Piruna et al. (2008) analyse the SLF with respect to both taxpayer interest rate subsidies and graduate loan repayment hardships. As found also 
by Ziderman (2003), it is clear that the SLF has very high interest rate subsidies and, consistent with this, it is associated with low repayment difficulties for former students.

The main contributions of this chapter are as follows. First, we present a comparison in conceptual terms of the costs and benefits of schemes such as the SLF with the other main alternative: income-contingent loans. Incomecontingent loans have advantages over mortgage-type loans in terms of providing insurance against both default and repayment hardships. A critical issue for this approach for many countries, however, concerns the efficacy of collection on the basis of a student's future income stream - it being the case that quite sophisticated institutional mechanisms are required. It is unclear to us whether or not the Thai income tax and/or pension collection schemes are such as to make effective and operative the collection of an income-contingent loan.

Using the same data, econometric approaches and accounting methods as those employed by Piruna et al. (2008), we are able to estimate the implicit interest rate subsidies for four different income-contingent loan arrangements, differing importantly with respect to collection parameters and interest rate regimes. For the first time in analyses of the effects of income-contingent loans, we demonstrate that the use of averages provides misleadingly low estimates of the extent of interest rate subsidies. As well, it appears that schemes with high first income thresholds of collection, and without a real rate of interest, are associated with significant interest rate subsidies, and, for high debts, these subsidies are not very dissimilar to those estimated for the SLF.

Further, it is also apparent that, for relatively low levels of debt income, contingent-loan policies with relatively low first income thresholds of repayment and with real rates of interest can be designed to be workable for Thailand in an aggregate financial sense. As debt levels increase, however, so too do the interest rate subsidies, with an important part of this result being due to the fact that Thai graduate incomes per capita are just not high enough for many groups to be able to repay all the debt before they leave the labour force.

Some important caveats are warranted. One is that we have not taken into account loan losses through poor collection outcomes, and this has the clear potential to reduce repayments and thus increase subsidies. Related to this is that graduate unemployment rates are quite high for the first several years after the completion of a university degree, and, from our calculations, with the SLF remain as high as 5 per cent even five years after labour-force participation begins. Taking this into account would necessarily increase subsidy estimates, and preliminary work in this area suggests that the figures would be about 5 percentage points higher. 
Finally, it has to be stressed that our conclusions are derived on the basis of particular design rules concerning different income-contingent loan approaches, and this should matter very significantly to the debate concerning the efficacy of income-contingent loan approaches in Thailand. The important point is that subsidy calculations are very sensitive to choices concerning: the first income threshold of repayment; the proportions of income required for loan repayment; and real interest rates. The next step is to ascertain the extent to which our broad conclusions are reinforced or compromised with alternative loan design parameters.

\section{References}

Barr, N. 2001, The Welfare State as Piggy Bank, Oxford University Press, UK.

Barr, N. 2007, Interest subsidies for income-contingent student loans, Mimeo., London School of Economics and Political Science, UK.

Carneiro, P. and Heckman, J. J. 2002, 'The evidence on credit constraints in postsecondary schooling', The Economic Journal, vol. 112, no. 482, pp. 705-30.

Chapman, B. 2006, Government Managing Risk: Income contingent loans for social and economic progress, Routledge, London.

Chapman, B. and Leigh, A. 2006, Do very high tax rates induce bunching? Implications for the design of income-contingent loan schemes, Discussion Paper No. 521, Centre for Economic Policy Research, The Australian National University, Canberra.

Chapman, B. and Lounkaew, K. 2008, 'HECS is in need of reform', Campus Review Weekly, January.

Dynarski, M. 1994, 'Who defaults on student loans: findings from the national post-secondary student aid study', Economics of Education Review, vol. 13, pp. 55-68.

Finnie, R. and Schwartz, S. 1996, Student Loans in Canada Past, Present and Future, C. D. Howe Institute, Toronto.

Freidman, M. 1955, 'The role of government in education', in A. Solo (ed.), Economics and the Public Interest, Rutgers University Press, New Brunswick, NJ, pp. 123-44.

Harding, A. 1995, 'Financing higher education: an assessment of incomecontingent loan options and repayment patterns over the life cycle', Education Economics, vol. 3, pp. 173-203. 
Lathapipat, D. 2008, The changing educational distribution and its impact on the evolution of wages in Thailand, 1987-2006, Paper prepared for Student Loans in South and East Asia Conference, Bangkok, 15-16 July.

Palacios, M. 2004, Investing in Human Capital, Cambridge University Press, UK.

Piruna, P., Sarachitti, R. and Thitima, S. 2008, Thailand's Student Loan Fund: an analysis of interest rate subsidies and repayment hardships, Paper prepared for Student Loans in South and East Asia Conference, Bangkok, 15-16 July.

Psacharopoulos, G. and Patrinos, H. A. 2002, Returns to Investment in Education: A further update, The World Bank, Washington, DC.

National Statistical Office 2006a, Labour Force Survey, 3rd Quarter, National Statistical Office, Bangkok.

National Statistical Office 2006b, National Statistical Year Book 2006, National Statistical Office, Bangkok.

Wooldridge, J. M. 2006, Introductory Econometrics: A modern approach, (Third edition), South-Western Thomson Learning, Sydney.

Ziderman, A. 2003, Student Loans in Thailand: Are they effective, equitable, sustainable?Volume 1. Policy Research and Dialogue Student Loans Schemes in Asia, United Nations Educational, Scientific and Cultural Organisation, Bangkok.

\section{Appendix 11.1}

Table A11.1 Years-of-schooling model

\begin{tabular}{lcrrr}
\hline \multirow{2}{*}{ Variable } & \multicolumn{2}{c}{ Female } & \multicolumn{2}{c}{ Male } \\
\cline { 2 - 5 } & Coefficient & t-stat & Coefficient & t-stat \\
\hline Schooling & $0.129^{* *}$ & 138.79 & $0.112^{* *}$ & 113.58 \\
Experience & $0.036^{* *}$ & 34.39 & $0.037^{* *}$ & 34.60 \\
Experience $/ 1000$ & $-0.1186^{* *}$ & -5.17 & $-0.178^{* *}$ & -8.13 \\
Constant & $1.692^{* *}$ & 133.93 & $1.979^{* *}$ & 164.27 \\
\hline $\mathrm{n}$ & 17491 & \multicolumn{3}{c}{19856} \\
$\mathrm{R}^{2}$ & 0.6146 & \multicolumn{3}{c}{0.5436} \\
\hline
\end{tabular}

* statistical significance at the 5 per cent level

${ }^{* *}$ statistical significance at the 1 per cent level 
Financing Higher Education and Economic Development in East Asia

Table A11.2 Dummy variables and interaction terms model

\begin{tabular}{|c|c|c|c|c|}
\hline \multirow{2}{*}{ Variable } & \multicolumn{2}{|c|}{ Female } & \multicolumn{2}{|c|}{ Male } \\
\hline & Coefficient & t-stat & Coefficient & t-stat \\
\hline Experience & $0.063 * *$ & 32.34 & $0.077 * *$ & 47.46 \\
\hline Experience $^{2}$ & $-0.001 * *$ & -34.55 & $-0.001 * *$ & -42.79 \\
\hline Primary & $0.150 * *$ & 3.65 & $0.146 * *$ & 3.83 \\
\hline Lower secondary & $0.254 * *$ & 7.28 & $0.221 * *$ & 5.49 \\
\hline Upper secondary & $0.315 * *$ & 9.64 & $0.350 * *$ & 8.33 \\
\hline Diploma & $0.577 * *$ & 11.79 & $0.548 * *$ & 9.26 \\
\hline Undergraduate & $0.776 * *$ & 28.39 & $0.859 * *$ & 19.37 \\
\hline Postgraduate & $1.025 * *$ & 15.95 & $1.104^{* *}$ & 11.48 \\
\hline Experience ${ }^{*}$ Primary $/ 100$ & $-0.019 * *$ & -4.12 & $-0.018 * *$ & -4.34 \\
\hline Experience $^{2 *}$ Primary $/ 10000$ & $0.006 * *$ & 4.92 & $0.007 * *$ & 3.58 \\
\hline Experience ${ }^{*}$ LowerSecondary/100 & $-0.023 * *$ & -4.79 & $-0.018 * *$ & -4.14 \\
\hline Experience $^{2 *}$ LowerSecondary/10 000 & $0.810 * *$ & 8.31 & $0.734 * *$ & 9.14 \\
\hline Experience ${ }^{*}$ UpperSecondary/100 & $0.008 * *$ & 4.14 & $0.005 * *$ & 3.60 \\
\hline Experience $^{2 *}$ UpperSecondary/10 000 & $-23.351 * *$ & -9.11 & $-30.058 * *$ & -9.39 \\
\hline Experience* Diploma/100 & $-0.003 * *$ & -4.13 & $0.023 * *$ & 3.90 \\
\hline Experience $^{2 *}$ Diploma/10 000 & $0.646 * *$ & 4.53 & $-0.205 * *$ & -1.51 \\
\hline Experience* Undergraduate/100 & $-0.009 * *$ & -2.66 & $-0.025 * *$ & -6.08 \\
\hline Experience $^{2 *}$ Undergraduate/10 000 & $0.845 * *$ & 10.19 & $0.822 * *$ & 7.70 \\
\hline Experience ${ }^{*}$ Postgraduate/100 & $0.026 * *$ & 2.31 & $0.028 *$ & 1.93 \\
\hline Experience $^{2 *}$ Postgraduate/10 000 & $-0.487^{* *}$ & -1.49 & $-0.861 * *$ & -2.24 \\
\hline Constant & $2.860 * *$ & 145.93 & $2.720 * *$ & 155.52 \\
\hline $\mathrm{n}$ & \multicolumn{2}{|c|}{17491} & \multicolumn{2}{|c|}{19856} \\
\hline $\mathrm{R}^{2}$ & \multicolumn{2}{|c|}{0.6146} & \multicolumn{2}{|c|}{0.5106} \\
\hline
\end{tabular}

* statistical significance at the 5 per cent level

** statistical significance at the 1 per cent level 
Table A11.3 Truncated OLS by income groups

\begin{tabular}{|c|c|c|c|c|c|c|}
\hline \multirow{2}{*}{ Variable } & \multicolumn{3}{|c|}{ Male } & \multicolumn{3}{|c|}{ Female } \\
\hline & 025 & 050 & 075 & 025 & 050 & 075 \\
\hline Constant & $2.5382^{* *}$ & $2.5804^{* *}$ & $2.6332 * *$ & $2.5621 * *$ & $2.6190 * *$ & $2.6571 * *$ \\
\hline \multicolumn{7}{|l|}{$\begin{array}{l}\text { Educational } \\
\text { attainment }\end{array}$} \\
\hline Primary & $0.1117 * *$ & $0.1553 * *$ & $0.2443 * *$ & $0.0744 * *$ & $0.1154 * *$ & $0.1840 * *$ \\
\hline Lower secondary & $0.2314 * *$ & $0.3002^{* *}$ & $0.4367^{* *}$ & $0.1857^{* *}$ & $0.2735 * *$ & $0.4003 * *$ \\
\hline Upper secondary & $0.3874 * *$ & $0.5331 * *$ & $0.7328 * *$ & $0.3542 * *$ & $0.4740 * *$ & $0.6615^{* *}$ \\
\hline Diploma & $0.6875^{* *}$ & $0.8419 * *$ & $1.0061 * *$ & $0.6610 * *$ & $0.8331 * *$ & $1.0663 * *$ \\
\hline Undergraduate & $0.8647^{* *}$ & $1.0676 * *$ & $1.2960 * *$ & $0.8280 * *$ & $0.9467^{* *}$ & $1.1260 * *$ \\
\hline Postgraduate & $1.7256^{* *}$ & $1.6819^{* *}$ & $1.5987^{* *}$ & $1.7043^{* *}$ & $1.8011^{* *}$ & $1.8186 * *$ \\
\hline \multicolumn{7}{|l|}{ Experience } \\
\hline Experience & $0.0337 * *$ & $0.0454 * *$ & $0.0506 * *$ & $0.0253^{* *}$ & $0.0312 * *$ & $0.0354^{* *}$ \\
\hline Experience $^{2}$ & $-0.0004 * *$ & $-0.0005^{* *}$ & $-0.0004^{* *}$ & $-0.0003^{* *}$ & $-0.0003^{* *}$ & $-0.0002 * *$ \\
\hline Undergrad*Exper & $0.0262 * *$ & $0.0196 * *$ & $0.0142 * *$ & $0.0266 * *$ & $0.0376 * *$ & $0.0389 * *$ \\
\hline Undergrad ${ }^{*}$ Exper $^{2}$ & 0.00001 & -0.0001 & $-0.0004^{* *}$ & $0.0002 * *$ & $-0.0003^{* *}$ & $-0.0006 * *$ \\
\hline Observations & & 19856 & & & 17491 & \\
\hline $\mathrm{R}^{2}$ & 0.2838 & 0.3736 & 0.4341 & 0.3950 & 0.4950 & 0.5301 \\
\hline
\end{tabular}

* statistical significance at the 5 per cent level

${ }^{* *}$ statistical significance at the 1 per cent level 